\title{
MISKONSEPSI MAHASISWA TENTANG EFEK FOTO LISTRIK
}

\author{
Hamdani \\ Dosen Pendidikan Fisika FKIP Universitas Tanjungpura \\ Email: hamdani@fkip.untan.ac.id
}

\begin{abstract}
This research was conducted to reveal students' misconceptions about the photoelectric effect. There were 58 students ( 13 male and 45 female) who answered 12 diagnostic test questions in the form of multiple-choice with open reasons. Misconceptions revealed include the order in which the colors of the rainbow disrupt photon energy; light intensity is affected by frequency; electron emission will occur when the light intensity and frequency of light are changed even though the frequency of the light used is smaller than the cutoff frequency. Male and female students have the same opportunity to misconceptions.
\end{abstract}

Keywords: Gender, Misconception, Photoelectric Effect

\section{PENDAHULUAN}

Mengungkap miskonsepsi yang dialami mahasiswa calon guru fisika belum banyak dilakukan pada Program Studi Pendidikan Fisika. Menurut Suparno (2005) miskonsepsi bisa terjadi pada siswa sekolah dasar hingga mahasiswa yang menempuh studi di perguruan tinggi. Penelitian mengungkap miskonsepsi yang dialami mahasiswa calon guru fisika (pre-service physics teacher) telah banyak dilakukan. Penelitian tersebut antara lain mengungkap miskonsepsi tentang kelistrikan (Baser, 2006); miskonsepsi tentang gaya (Bayraktar, 2008); miskonsepsi tentang gravitasi (Kaltakçi dan Didiş, 2007); miskonsepsi tentang optika geometris (Kaltakci, Eryilmaz, dan McDermott, 2016); miskonsepsi tentang astronomi (Kanli, 2014; Gurbuz, 2016); miskonsepsi tentang fluida (Hamdani, 2015); miskonsepsi tentang suhu dan kalor (Frederik, Der Valk, Leite, dan Thorén, 1999).

Jika mahasiswa mengalami miskonsepsi maka besar kemungkinan miskonsepsi tersebut akan "ditularkan" pada siswa yang diajarnya kelak. Oleh karena itu miskonsepsi yang dialami mahasiswa perlu diatasi dengan tepat. Mengungkap miskonsepsi merupakan langkah awal untuk mengatasi miskonsepsi. Pembelajaran untuk meremediasi miskonsepsi akan berhasil, jika pembelajaran tersebut dirancang berdasarkan bentuk-bentuk miskonsepsi yang ada.

Materi fisika yang abstrak merupakan salah satu penyebab miskonsepsi akan muncul pada materi tersebut. Efek foto listrik merupakan salah satu materi fisika yang abstrak, karena proses elektron yang mengalir pada rangkaian tidak bisa diamati secara langsung. Miskonsepsi pada materi efek foto listrik belum pernah diungkap di Program Studi Pendidikan Fisika baik oleh mahasiswa ketika menyelesaikan skripsi atau oleh dosen ketika melakukan penelitian. Oleh karena itu perlu dilakukan penelitian mengungkap miskonsepsi tentang efek foto listrik, agar diperoleh bentuk-bentuk miskonsepsi pada materi efek foto listrik. Masalah dalam peneilitian ini (1). Bagaimana profil miskonsepsi mahasiswa calon guru fisika tentang efek foto listirk?; (2). Apakah terdapat perbedaan miskonsepsi tentang efek foto listrik antara mahasiswa laki-laki dengan mahaiswa perempuan?

\section{METODE PENELITIAN}

Fokus penelitian ini mendeskripsikan bentuk-bentuk miskonsepsi mahasiswa tentang efek foto listrik. Oleh karena itu metode deskriptif digunakan dalam penelitian ini dengan bentuk penelitian survey. Ada 58 orang 
mahasiswa (13 laki-laki dam 45 perempuan) yang mengontrak mata kuliah Fisika Modern disajdikan sampel dalam penelitian ini. Sebanyak 12 buah soal tes diagnostik berbentuk pilihan ganda dengan alasan terbuka yang dinyatakan valid dan reliabel $(0,63)$ diberikan pada mahasiswa untuk mengungkap miskonsepsi tentang efek foto listrik. Uji chi kuadrat menggunakan SPSS 23 dilakukan untuk mencari ada atau tidak ada perbedaan miskonsepsi antara mahasiswa laki-laki dengan mahasiswa perempuan.

\section{HASIL DAN PEMBAHASAN}

Jawaban mahasiswa dianalisis secara deskriptif untuk mengidentifikasi bentukbentuk miskonsepsi mahasiswa tentang efek foto listrik dan analisis kuantitatif dilakukan untuk mencari apakah terdapat perbedaan miskonsepsi antara mahasiswa laki-laki dengan mahasiswa perempuan.. Alasan mahasiswa dengan gagasan yang sama dikelompokan dalam konsepsi yang sama. Bentuk-bentuk miskosepsi yang berhasil diungkap disajikan pada Tabel 1

Tabel 1 Bentuk-bentuk miskonsepsi tentang efek foto listrik

\begin{tabular}{|c|c|}
\hline Bentuk Miskonsepsi & $\begin{array}{c}\text { Jumlah } \\
\text { Mahasiswa (\%) }\end{array}$ \\
\hline Frekuensi warna biru lebih kecil dibandingkan frekuensi warna hijau & $16(27,6)$ \\
\hline $\begin{array}{l}\text { Panjang gelombang warna kuning lebih besar diabndingkan dengan panjang } \\
\text { gelombang warna merah }\end{array}$ & $16(27,6)$ \\
\hline Semakin besar panjang gelombang maka semakin besar frekuensi gelombang & $16(27,6)$ \\
\hline $\begin{array}{l}\text { Energi foton warna kuning lebih besar dibandingkan dengan energi foton warna } \\
\text { merah }\end{array}$ & $11(18,9)$ \\
\hline Energi foton warna kuning sama besar dengan energi foton warna merah & $7(12,1)$ \\
\hline Energi foton warna biru lebih kecil dibandingkan dengan foton warna hijau & $24(41,4)$ \\
\hline Energi foton warna biru sama dengan energi foton warna hijau & $2(3,4)$ \\
\hline $\begin{array}{l}\text { Pada percobaan efek foto listrik ketika frekuensi diperbesar maka intensitas cahaya } \\
\text { yang mengenai pelat katoda akan bertambah }\end{array}$ & $37(63,8)$ \\
\hline $\begin{array}{l}\text { Pada percobaan efek foto listrik ketika frekuensi diperbesar maka intensitas cahaya } \\
\text { yang mengenai pelat katoda akan berkurang }\end{array}$ & $11(18,9)$ \\
\hline $\begin{array}{l}\text { Pada percobaan efek foto listrik frekuensi yang diperkecil namun lebih kecil dari } \\
\text { frekuensi ambang maka semakin banyak elektron yang keluar (teremisi) dari } \\
\text { katoda }\end{array}$ & $17(29,3)$ \\
\hline $\begin{array}{l}\text { Pada percobaan efek foto listrik frekuensi yang diperkecil namun lebih kecil dari } \\
\text { frekuensi ambang maka semakin sedikit elektron yang keluar (teremisi) dari katoda }\end{array}$ & $34(58,6)$ \\
\hline $\begin{array}{l}\text { Pada percobaan efek foto listrik frekuensi yang diperbesar namun lebih kecil dari } \\
\text { frekuensi ambang maka semakin banyak elektron yang keluar (teremisi) dari } \\
\text { katoda }\end{array}$ & $35(60,3)$ \\
\hline $\begin{array}{l}\text { Pada percobaan efek foto listrik frekuensi yang diperbesar namun lebih kecil dari } \\
\text { frekuensi ambang maka semakin sedikit elektron yang keluar (teremisi) dari katoda }\end{array}$ & $11(18,9)$ \\
\hline $\begin{array}{l}\text { Pada percobaan efek foto listrik intensitas diperbesar dan frekuensi yang } \\
\text { ditembakan tidak lebih besar dari frekuensi ambang maka semakin banyak elektron } \\
\text { yang keluar dari katoda }\end{array}$ & $12(20,7)$ \\
\hline $\begin{array}{l}\text { Pada percobaan efek foto listrik intensitas diperbesar dan frekuensi yang } \\
\text { ditembakan tidak lebih besar dari frekuensi ambang maka semakin sedikit elektron } \\
\text { yang keluar dari katoda }\end{array}$ & $30(51,7)$ \\
\hline $\begin{array}{l}\text { Pada percobaan efek foto listrik intensitas diperbesar dan frekuensi yang } \\
\text { ditembakan lebih besar dari frekuensi ambang maka semakin sedikit elektron yang } \\
\text { keluar dari katoda }\end{array}$ & $12(20,7)$ \\
\hline
\end{tabular}




\begin{tabular}{lc}
\hline $\begin{array}{l}\text { Pada percobaan efek foto listrik intensitas diperbesar dan frekuensi yang } \\
\text { ditembakan lebih besar dari frekuensi ambang maka tidak ada elektron yang keluar } \\
\text { dari katoda }\end{array}$ & $10(17,2)$ \\
\hline $\begin{array}{l}\text { Pada percobaan efek foto listrik frekuensi diperkecil namun melebihi frekuensi } \\
\text { ambang maka semakin banyak elektron yang keluar (teremisi) dari katoda }\end{array}$ & $17(29,3)$ \\
\hline $\begin{array}{l}\text { Pada percobaan efek foto listrik frekuensi diperkecil namun melebihi frekuensi } \\
\text { ambang maka tidak ada elektron yang keluar (teremisi) dari katoda }\end{array}$ & $5(8,6)$ \\
\hline $\begin{array}{l}\text { Pada percobaan efek foto listrik frekuensi yang ditembakan diperbesar namun lebih } \\
\text { kecil dari frekuensi ambang maka semakin besar energi kinetik elektron }\end{array}$ & $37(63,8)$ \\
\hline $\begin{array}{l}\text { Pada percobaan efek foto listrik frekuensi yang ditembakan diperbesar namun lebih } \\
\text { kecil dari frekuensi ambang maka semakin besar energi kinetik elektron }\end{array}$ & $13(22,4)$ \\
\hline
\end{tabular}

Mahasiswa laki-laki yang menjawab tes diagnostik sebanyak 13 orang dan ada 45 orang mahasiswa perempuan yang terlibat dalam penelitian ini. Rata-rata persentase mahasiswa laki-laki mengalami miskonsepsi sebesar $59,44 \%$ dan mahasiswa perempuan sebesar $58,72 \%$ yang disajikan pada Gambar 1 .

\section{Gambar 1. Rata-rata Persentase Miskonsepsi Mahaasiswa Laki-Laki dan Mahasiswa Perempuan.}

Pada Gambar 2 disajikan diagram batang perbandingan rata-rata persentase miskonsepsi tiap nomor soal antara mahasiswa laki-laki dengan mahasiswa perempuan.

Miskonsepsi yang diungkap terjadi pada semua indikator yang diteliti. Miskonsepsi banyak dialami mahasiswa pada materi yang dipelajari, saat materi yang terkait (pra syarat) terdapat miskonsepsi. Ada 16 orang $(27,6 \%)$ yang miskonsepsi tentang hubungan warna, frekuensi dan panjang gelombang. Miskonsepsi ini berdampak pada pemahaman mahasiswa tentang hubungan energi foton dengan frekuensi pada warna yang berbeda. Mahasiswa yang menganggap frekuensi warna biru lebih kecil dibandingkan dengan frekuensi warna hijau, juga menganggap energi foton warna biru lebih kecil 


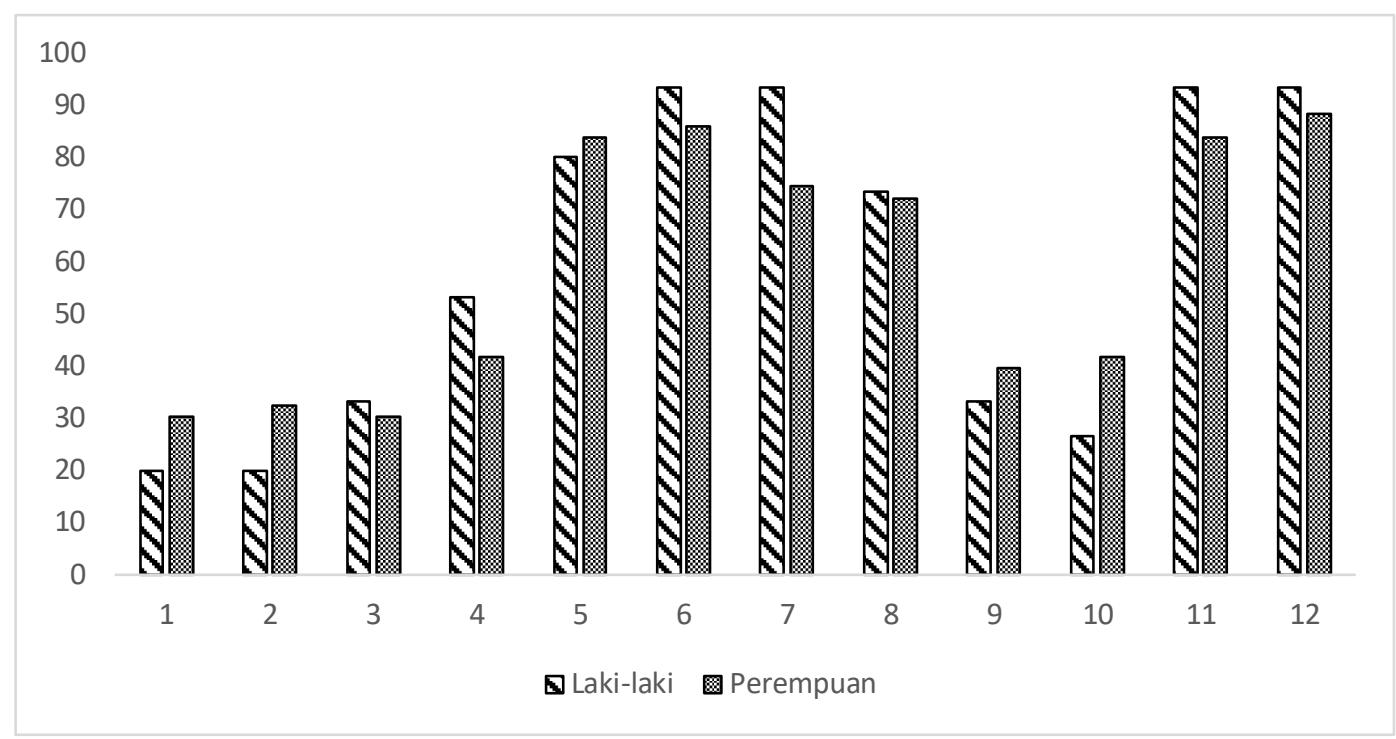

\section{Gambar 2. Persentase Jumlah Mahasiswa Laki-Laki dan Mahasiswa Perempuan yang mengalami Miskonsepsi tiap Nomor Soal}

dibandingkan dengan energi foton warna hijau. Miskonsepsi ini menjelaskan urutan warna pelangi mengacaukan besar energy foton (cahaya). Bentuk miskonsepi serupa juga ditemukan oleh Habibbulloh (2018).

Hampir semua mahasiswa $(82,7 \%)$ menganggap bahwa intensitas cahaya pada

Pada percobaan efek foto listrik sebagian besar mahasiswa belum memahami frekuensi ambang pada logam yang dikenai cahaya monokromatik. Pada saat frekuensi cahaya yang ditembakan lebih kecil dari frekuensi ambang logam, ada 17 orang $(29,3 \%)$ mahasiswa menganggap jika frekuensi cahaya diperkecil maka semakin banyak emisi elektron (elektron yang keluar dari katoda) dan lebih dari separuh $(58,6 \%)$ mahasiswa menganggap jika frekuensi cahaya diperkecil maka semakin sedikit emisi elektron. Persentase jumlah mahasiswa yang miskonsepsi tak jauh berbeda ditemukan ketika frekuensi diperbesar tetapi lebih kecil dari frekuensi ambang. Mahasiswa yang menganggap semakin besar frekuensi maka semakin banyak emisi elektron digolongkan miskonsepsi karena emisi elektron tidak terjadi jika frekuensi cahaya yang ditembakan tidak lebih besar dari frekuensi ambang. Mahasiswa juga menganggap emisi elektron akan berkurang ketika intensitas cahaya diperbesar $(51,7 \%)$ dan emisi elektron akan bertambah ketika intensitas cahaya diperkecil (20,7). Mahasiswa menganggap intensitas cahaya mempengaruhi emisi elektron, percobaan efek foto listrik dipengaruhi oleh frekuensi. Bentuk miskonsepsi yang diungkap antara lain jika frekuensi diperbesar maka intensitas cahaya bertambah $(63,8 \%)$ dan jika frekuensi diperbesar maka intensitas cahaya berkurang (18,9\%). Habibbulloh (2018) juga menemukan miskonsepsi yang sama.

miskonsepsi ini juga ditemukan dalam penelitian McKagan, et al (2009) dan Taslidere (2016). Berdasarkan temuan ini mahasiswa menganggap emisi elektron akan terjadi ketika intensitas cahaya dan frekuensi cahaya diubah nilainya walaupun frekeunsi cahaya yang mengnai katoda lebih kecil dari frekuensi ambang. Mahasiswa juga mengangap energi kinetik elektron akan bertambah ketika frekuensi diperbesar walaupun frekuensi tersebut lebih kecil dari frekuensi ambang.

Mencari ada atau tidak ada perbedaan miskonsepsi mahasiswa laki-laki dengan mahasiswa perempuan tentang efek foto listrik dilakukan dengan cara menggunakan uji chi kuadrat. Uji chi kuadrat dilakukan tiap nomor soal menggunakan SPSS 23. Berdasarkan hasil uji chi kuadrat pada semua nomor soal, diperoleh kesimpulan tidak terdapat perbedaan miskonsepsi antara mahasiswa laki-laki dengan mahasiswa perempuan. Hal ini menunjukkan mahasiswa laki-laki dan mahasiswa perempuan memiliki peluang yang sama untuk mengalami miskonsepsi tentang efek foto listrik. Secara lengakap uji chi kuadrat disajikan pada tabel di bawah ini. 
Tabel 2 Rekapitulasi Uji Chi Kuadrat tiap Nomor Soal

\begin{tabular}{cccccc}
\hline $\begin{array}{c}\text { No } \\
\text { soal }\end{array}$ & $\begin{array}{c}\text { Laki-Laki } \\
(\boldsymbol{\%})\end{array}$ & $\begin{array}{c}\text { Perempuan } \\
(\boldsymbol{\%})\end{array}$ & Total $(\boldsymbol{\%})$ & $\begin{array}{c}\text { Chi square } \\
\text { (asymp.sig) }\end{array}$ & Keputusan \\
\hline 1 & $3(20,0)$ & $13(30,2)$ & $16(27,6)$ & 0,445 & Ho diterima \\
\hline 2 & $3(20,0)$ & $14(32,6)$ & $17(29,3)$ & 0,358 & Ho diterima \\
\hline 3 & $5(33,3)$ & $13(30,2)$ & $18(31,1)$ & 0,823 & Ho diterima \\
\hline 4 & $8(53,3)$ & $18(41,9)$ & $26(44,8)$ & 0,442 & Ho diterima \\
\hline 5 & $12(80,0)$ & $36(83,7)$ & $48(82,8)$ & 0,743 & Ho diterima \\
\hline 6 & $14(93,3)$ & $37(86,1)$ & $51(87,9)$ & 0,456 & Ho diterima \\
\hline 7 & $14(93,3)$ & $32(74,4)$ & $46(79,3)$ & 0,119 & Ho diterima \\
\hline 8 & $11(73,3)$ & $31(72,1)$ & $42(72,4)$ & 0,926 & Ho diterima \\
\hline 9 & $5(33,3)$ & $17(39,5)$ & $22(37,9)$ & 0,67 & Ho diterima \\
\hline 10 & $4(26,7)$ & $18(41,9)$ & $22(37,9)$ & 0,296 & Ho diterima \\
\hline 11 & $14(93,3)$ & $36(83,7)$ & $50(86,2)$ & 0,353 & Ho diterima \\
\hline 12 & $14(93,3)$ & $38(88,4)$ & $52(89,7)$ & 0,587 & Ho diterima \\
\hline
\end{tabular}

Berdasarkan uji chi-kuadrat pada semua nomor, ditemukan tidak ada perbedaan miskonsepsi tentang efek foto listrik antara mahasiswa laki-laki dengan mahasiswa perempuan. Dengan kata lain mahasiswa lakilaki dan mahasiswa perempuan memiliki peluang yang sama untuk mengalami miskonsepsi tentang efek foto listrik. Hasil ini didukung oleh penelitian Crouch dan Mazur (2001) ; Kola (2017) yang menyatakan tidak ada kesenjangan gender dalam memahami fisika dikalangan mahasiswa.

\section{KESIMPULAN DAN SARAN Kesimpulan}

Rata-rata persentase jumlah mahasiswa yang mengalami miskonsepsi tentang efek foto listrik sebesar 60,34\%. Bentuk-bentuk miskonsepsi yang berhasil diungkap antara lain

\section{REFERENSI}

Baser, M. (2006). Effects of Conceptual Change and Traditional Confirmatory Simulations on Pre-Service Teachers' Understanding of Direct Current Circuits. Journal of Science Education and Technology, 15(5-6), 367-381. doi:10.1007/s10956-0069025-3

Bayraktar, S. (2008). Misconceptions of Turkish Pre-Service Teachers about Force and Motion. International mahasiswa mengangap semakin besar frekuensi maka semakin besar panjang gelombang; semakin kecil frekuensi maka semakin besar energi foton; frekuensi diperbesar maka intensitas cahaya bertambah; pada percobaan efek foto listrik jika frekuensi yang digunakan lebih kecil dari frekuensi ambang maka frekuensi yang diperbesar atau diperkecil akan mempengaruhi jumlah elektron yang teremisi.

\section{Saran}

Tidak ada perbedaan miskonsepsi antara mahasiswa laki-laki dengan mahasiswa perempuan pada semua indikator. Penyebab miskonsepsi dan pemilihan model atau metode yang sesuai perlu dikaji untuk diterapkan sebagai upaya mengatasi miskonespi yang dialami mahasiswa tentang efek foto listrik

\section{Journal of Science and Mathematics Education, 7(2), 273-291. doi:10.1007/s10763-007-9120-9}

Crouch, C.H., \& Mazur, E. (2001). Peer instruction: Ten years of experience and results. American Journal of Physics, 69(9), 970-977

De Leone, C. J. \& Oberem, G. E. (2004). Toward Understanding Student Conceptions of the Photoelectric Effect. AIP Conference Proceedings. doi:10.1063/1.1807260 
Gurbuz, F. (2016). Physics Education: Effect of Micro-teaching Method Supported by Educational Technologies on Preservice Science Teachers' Misconceptions on Basic Astronomy Subjects. Journal of Education and Training Studies. 4 (2), 27-41

Frederik, I., Der Valk, T. V., Leite, L., \& Thorén, I. (1999). Pre-service Physics Teachers and Conceptual Difficulties on Temperature and Heat. European Journal of Teacher Education, 22(1), 61-74. doi:10.1080/0261976990220105

Habibbulloh, M. (2018). Analisis Ragam Miskonsepsi Siswa Pada Konsep Efek Foto Listrik. Reforma: Jurnal Pendidikan dan Pembelajaran. 7 (2), 48-54

Hamdani. (2015). Penerapan Virtual laboratory Untuk Mereduksi Miskonsepsi Mahasiswa Tentang Fluida. Jurnal Visi Ilmu Pendidikan. 7 (3), 1781-1788. DOI:

http://dx.doi.org/10.26418/jvip.v7i3.1 7181

Kaltakçi, D., \& Didiş, N. (2007). Identification of Pre-Service Physics Teachers' Misconceptions on Gravity Concept: A Study with a 3-Tier Misconception Test. AIP Conference Proceedings. doi:10.1063/1.2733255

Kaltakci-Gurel, D., Eryilmaz, A., \& McDermott, L. C. (2016). Identifying pre-service physics teachers' misconceptions and conceptual difficulties about geometrical optics. European Journal of Physics, 37(4), 045705. doi:10.1088/01430807/37/4/045705

Kanli, U. (2014). A Study on Identifying the Misconceptions of Pre-service and Inservice Teachers about Basic Astronomy Concepts. EURASIA Journal of Mathematics, Science \& Technology Education, 10(5), 471479. doi:10.12973/eurasia.2014.1120a

Kola, A.J. (2017). Investigating the Conceptual Understanding of Physics through an Interactive Lecture Engagement. Cumhuriyet International Journal of Education, Vol 6 (1), 82 - 96

McKagan, S. B., W. Handley, K. K. Perkins, and C. E. Wieman. 2009. "A ResearchBased Curriculum for Teaching the Photoelectric Effect." American Journal of Physics 77 (1): 87-94.

Suparno, P (2005). Miskonsepsi dan Perubahan Konsep Pendidikan Fisika. Jakarta: Grasindo

Taslidere E. (2016). Development and Use of a Three-Tier Diagnostic Test to Assess High School Students' Misconceptions About The Photoelectric Effect. Research In Science \& Technological Education. 34(2), 164-186 